\title{
Spor Lisesi ve Spor Bilimleri Fakültesi Öğrencilerinin Öfke ve Saldırganlık Düzeylerinin Araştırılması
}

\author{
DOI: $10.26466 /$ opus.592641
}

\section{Bade Yamak ${ }^{*}$ - Osman İmamoğlu ${ }^{* *}$ - Murat Eliöz ${ }^{* * *}$-Mehmet Çebi ${ }^{* * *}$ İzzet İslamoğlu $\mathrm{u}^{* * * * *}$}

* Dr. Öğr. Üyesi Dr. Ondokuz Mayıs Üni., Yaşar Doğu Spor Bilimleri Fak, Samsun / Türkiye E-Posta: badetekbas@gmail.com

ORCID: $\quad$ 0000-0002-7129-0346

** Prof. Dr. Ondokuz Mayıs Üniversitesi, Yaşar Doğu Spor Bilimleri Fakültesi, Samsun / Türkiye

E-Posta: osmani55@hotmail.com

ORCID: $\quad$ 0000-0001-6671-6042

*** Doç. Dr. Ondokuz Mayıs Üniversitesi, Yaşar Doğu Spor Bilimleri Fakültesi, Samsun / Türkiye

E-Posta: muratelioz@hotmail.com

ORCID: $\quad$ 0000-0002-7641-7772

**** Doç. Dr. Ondokuz Mayıs Üniversitesi, Yaşar Doğu Spor Bilimleri Fakültesi, Samsun / Türkiye E-Posta mcebi73@hotmail.com ORCID: 0000-0002-4055-728X

*****Arş. Gör. Ondokuz Mayıs Üniversitesi, Yaşar Doğu Spor Bilimleri Fakültesi, Samsun / Türkiye E-Posta izzetislamoglu@gmail.com

ORCID: $\quad \underline{0000-0001-5573-1423}$

\section{Öz}

Bu çalı̧mada spor lisesi ve spor bilimleri fakültesi öğrencilerinin sürekli öfke-öfke ifade şekilleri ve saldırganlık düzeylerinin araştırılması amaçlanmıştır. Çalışmaya 113 Spor Lisesi ve 146 Spor Bilimleri Fakültesi öğrencisi dahil edilmiştir. Öğrencilere Buss-Perry Saldırganlık Anketi ve Sürekli Öfke ve öfke ifade Ölçeği uygulanmıştır. İstatistiksel işlemlerde t-testi kullanılmıştır. Cinsiyete göre sürekli öfke durumunda ve öfke dışta anlamlı farklllk varken $(p<0,05)$ ve öfke içte ve öfke kontrol şekilleri arasında anlamlı bir farkllık bulunmamıştır $(p>0,05)$. Lise ve Üniversite öğrencisi olma durumuna göre sürekli öfke ve öfke ifade şekilleri arasinda (öfke içte hariç) anlamlı bir farklilk bulunmuştur ( $p<0,05, p<0,001)$. Cinsiyete göre fiziksel saldirganlik ve düşmanlık alt boyutunda anlamlı bir farklllk bulunmuştur $(p<0,05)$. Öfke ve sözel saldrrganlık alt boyutunda ve toplam saldırganlıkta cinsiyete göre anlaml bir farklilık bulunmamıştır ( $p>0,05)$. Spor lisesi ve spor bilimleri fakültesi öğrencilerinde fiziksel saldırganlık ve öfke alt boyutu ile toplam saldırganlıkta anlamlı bir farkllık bulunmuştur $(p<0,05$ ve $p<0,001)$. Öfke ve saldırganlı ölçekleri alt ölçekler ve toplam puanlar arasında öfke kontrolü hariç pozitif korelasyonlar bulunmuştur. Öfke kontrolü ile ise negatif korelasyonlar bulunmuştur $(p<0,05$ ve $p<0,001)$. Erkeklerin sürekli öfke düzeyinin kadınlardan daha yüksek olduğu söylenebilir. Erkekler kadınlara göre öfkelerini daha kolayca ifade edebilmişlerdir. Spor bilimleri fakültesi öğrencileri spor lisesi öğrencilerine göre öfkelerini daha kolay dışa yansıtabilmektedirler. Spor lisesi ö̆rrencileri üniversite öğrencilerine göre öfkelerini daha iyi kontrol edebilmişlerdir.

Anahtar Kelimeler: Öğrenci, öfke, saldırganlık 


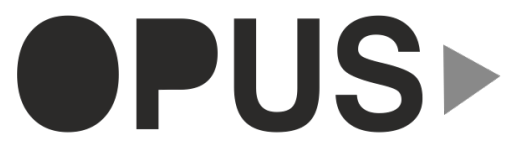

Uluslararası Toplum Araştırmaları Dergisi International Journal of Society Researches
E-ISSN : 2528-9535

YIl Year: 9

Cilt Volume: 14

Sayı Issue :20

Aralık December 2019

Makalenin Gelis Tarihi Received Date: 16/07/2019

Makalenin Kabul Tarihi Accepted Date: 14/11/2019

\title{
Investigation of Anger and Aggression Levels of Sports High School and Sports Science Faculty Students
}

\begin{abstract}
In this study, it was aimed to investigate the anger-anger expression patterns and aggression levels of sports high school and sports science faculty students. 113 Sports High School and 146 Sports Science Faculty students were included in the study. Buss-Perry Aggression Questionnaire and the Trait Anger and Anger Expression Scale were applied to the students. T-test was used in statistical procedures. There was a significant difference $(p<0.05)$ between the anger status and the anger control styles $(p>0.05)$. There was a significant difference between high anger and anger expressions (except anger inside) $(p<0.05, p<0.001)$. There was a significant difference in physical aggression and hostility subdimension according to gender $(p<0.05)$. There was no significant difference in anger and verbal aggression sub-dimension and total aggression by gender ( $p>0.05)$. There was a significant difference between physical aggression and anger subscale and total aggression among sports high school and sports faculty students $(p<0.05$ and $p<0.001)$. There were positive correlations between anger and aggression scales and total scores except anger control. There were negative correlations with anger control $(p<0.05$ and $p<0.001)$. Conclusion: It can be said that men's anger level is higher than women. Men were able to express their anger more easily than women. Sports faculty students can express their anger more easily than sports high school students. Sports high school students were better able to control their anger than university students.
\end{abstract}

Keywords: Student, anger, aggression 


\section{Giriş}

Öfke normal, herkes tarafından hissedilebilen, vazgeçilemeyen, güçlü fakat kontrol edilmesi öğrenilen bir duygudur. Aynı zamanda, öfke; hem klinik hem de klinik olmayan durumlarda teşhisi kolaylaştıran bir boyut olarak görülmektedir. Kişilerin öfke yasamasına neden olan; engellenme, haksızlığa uğrama, fiziksel incinme ve yaralanmalar, cinsel taciz, hayal k1rıklığı, saldırıya uğrama ve tehdit gibi birçok faktörden söz edilebilmektedir (Kökdemir, 2004). Öfke, sevgi, açlık, yorgunluk ve yalnızlık gibi temel duygulardan birisidir. Literatürde öfke kelimesi çoğu zaman düşmanlık, saldırganlık ve şiddet ile birlikte ele alınmaktadır (Karadağ, 2018). Birçok psikolojik yapı ile ilişkili olduğu gözlemlenen ve birçok davranışın belirleyicisi durumunda olan yetkinlik inancının önemli boyutlarından biri olan sosyal yetkinliğin öfke ve öfke ifade biçimleri ile de ilişki göstermesi beklenmektedir (Bandura, 1986; Bandura, 1989; Bandura ve ark., 1999). Buna paralel olarak duygu, düşünce ve beklentilerini açıkça belirtme konusunda sosyal beceri yoksunluğu yasayan bireylerin sosyal yeterliliklerinin azaldığı gözlenirken, bireylerin bu yetersizliklerinden dolayı dışarıdan gelen tahriklere yetersiz cevap verdikleri ve konuda uzun süreli düşündükleri gözlenmektedir (Alden ve Wallace, 1995). Sosyal yeterliliğin azalması, bireyin sosyal kaygısını artırmakta ve öfkesini kontrol etme yeteneklerini olumsuz yönde etkileyebilmektedir (Weber ve ark., 2007). Üniversite ortamı da pek çok öğrenci için yeni bir çevre ve ilişkiye başlama, kendi yaşadığı yeri ve harcamalarını ilk kez yönetme, başkalarının duygularını anlamaya çalışma ve düşüncelerini savunmak gibi yaşamsal olayları kapsayan bir süreçtir. Bu süreçte ihtiyaçların karşılamaması ve beklentilerin gerçekleşmemesi durumunda ortaya çıkması beklenen sorunlardan biri de öfkedir (Çengiz ve ark., 2018). Ayrıca, Özer (1990), büyük şehirlerdeki gürültü, trafik sıkışıklığı, mekân darlığı, ekonomik hayatın zorluklarını öfke uyandıran nedenler olarak belirtmektedir. Araştırmalar, öfkenin fiziksel ve sözel saldırganlık, çocuklukta cinsel ve fiziksel istismara uğramış olma, düşük problem çözme becerisi, yüksek alkol kullanımı, yüksek düzeyde stres ve algılanan sosyal destek seviyesinin düşük olması ile ilişkili olduğunu göstermektedir. Sürekli öfkeli olan bireylerin, uzun süreli, çok şiddetli ve sıklıkla öfke yaşantısını geçirmiş olmalarının öfke açısından önemli bir özellik olduğu ileri sürülmektedir 
(Esen ve Çelikkaleli, 2002). Bilişsel olarak olayları algılama, değerlendirme ve düşüncelerimizle ilişkili olarak herhangi bir sözel ya da görsel uyarıcının fiziksel ya da psikolojik bütünlügümüzü tehdit edici, engelleyici, küçümseyici, yaralayıcı, incitici olarak algılanması öfke tepkilerini harekete geçirebilmektedir. Öfkenin davranışsal boyutu, bastırma ya da dışa vurma seklinde yansıyabilmektedir. Genellikle bastırılmış öfke daha tehlikeli olarak değerlendirilir. Ancak dışa yansıtılan öfke de özellikle kişiler arası ilişkiler açısından zaman zaman yıkıcı, yıpratıcı etkilere sahiptir (Yöndem ve Bıçak, 2008). Sağlıklı ifade edilmeyen öfkenin, olumsuz birçok yönü vardır. Öfke kişilerarası ilişkilere zarar verdiğinde sağlıksız bir duygu halini almış demektir. Öfke kötüye kullanımı açısından diğer duygulardan ayrılır. Sağlıksız öfkenin içeriğinde zarar verme ve sık sık saldırganlık vardır (Genç, 2007). Öfke hem ilişkileri zorlaştırması hem de zarar verme potansiyeli nedeniyle bas edilmesi gereken önemli bir duygu durumudur (Canbuldu, 2006). Her tür öfkenin kişiyi uyarıcı, koruyucu veya harekete geçirici bir işlevi vardır. Dolayısıyla öfke organizmayı bir problem olduğunda uyarır ve kendisine zarar verici veya saldırgan davranma eğiliminden kişiyi haberdar etmede etkin bir rol oynar (Soykan, 2003). Öfke ifadesinde sorun yaşayan öğrencilerin sosyal ve toplumsal becerilerinin artması için kulüp faaliyetlerinde aktif olarak sorumluluk almasının sağlanması; boş zaman etkinliklerine katılımının sağlanması yararlı olacağı belirtilir (Çengiz ve ark., 2018).

Saldırganlık okul öncesi dönemden üniversiteye kadar her öğretim kademesindeki bireylerde görülebilen ve olumsuz özelliklerle ilişkili bir davranıştır (Camadan ve Yazıcı, 2017). Saldırganlık sözlü, fiziksel ya da dolaylı olarak bir başkasına zarar vermeyi amaçlayan herhangi bir harekettir. Saldırganlık sözcüğü genelde olumsuz bir davranış olarak algılanmasına rağmen, temel anlamda bir yere veya kimseye yaklaşmak, bir şeye başlamak fakat aynı zamanda saldırmak üzere atılmak anlamlarına gelmektedir. Fakat günümüzde saldırganlık, canlı ya da cansız herhangi bir objeye zarar verici, yaralayıcı, hatta öldürücü, zedeleyici davranışlar olarak tanımlanmaktadır (Kesen ve ark., 2007). Saldırganlıkta ise kişi ya da grup tarafından diğerine zarar vermek amacıyla davranış gerçekleştirilmektedir. Saldırganlık bir davranış olarak tanımlandığında, davranışa dönüştürülemeyen düşmanlık duyguları tanımın dışında bırakılmaktadır. 
Fiziksel saldırganlık (örneğin, birisine vurma) ve sözel saldırganlık (örneğin, aşağılama, suçlama) ise tanıma dahil edilmektedir (Bilgin, 1988). Sporda saldırganlık, sportif yarışma veya müsabaka esnasında bahsedilen olaya dahil olan öğelerden (sporcu, antrenör, seyirci) bir veya birkaçının psikolojik, biyolojik ya da sosyal faktörlerden etkilenerek, spor dalına özgü belirlenmiş kurallarının dışına çıkarak, karşısındakine zarar vermek ya da bir hedefe ulaşmak amacıyla gerçekleştirdiği sözel ya da fiziksel eylemler olarak tanımlanabilir (Dervent ve ark., 2010). Sportif faaliyetlerdeki mücadele hırsı, aşırı efor sarf etme, kazanmak için yüksek düzeyde stres altında olma gibi durumlar bireyi saldırgan ve kontrolsüz yapabilmektedir (Erdoğdu ve ark., 2018). Saldırganlığın boyutları olarak sözel saldırganlık, öfke, düşmanlık ve şiddet verilebilir. Sözel saldırganlık, bireyin karşısındaki kişiyi hakaret etme, alay etme ve bağırma gibi sözel ifadeler aracılığıyla incitmesidir (Ramirez ve Andreu, 2006; Roberto et al., 2003). Öfke, bireyin ihtiyaçlarını karşılayamadığı veya istemediği yaşantılara maruz kaldığı durumlarda yaşadığı bir duygu olarak kabul edilir (Soysal et al., 2009; Tafrate et al., 2002). Düşmanlık, kişinin diğer kişiye karşı geliştirdiği düşünce içerikli olumsuz yaklaşımlar olarak tarif edilir (Demirtaş Madran, 2013). Şiddet ise kişinin kendisine veya karşıdaki kişiye yönelik olarak sergilediği fiziksel içerikli vurma, kırma veya yaralama şeklinde kasitlı ve zarar verici tepkiler olarak tanımlanabilir (Boxer ve Tisak, 2005; Ramirez ve Andreu, 2006).

Saldırganlık ve öfke kişinin kendisine veya başkasına zarar veren bir davranış biçimi ve toplum tarafından onaylanmayan olumsuz bir tutumu ortaya koymaktadır. Sportif yarışma veya müsabaka sırasında kişinin mücadele hırsı, aşırı efor sarf etme, kazanmak için yüksek düzeyde baskı altında olma gibi durumlar bireyi öfkeli ve saldırgan bir duruma getirebilmektedir. Bu olumsuz özellikleri en aza indirmek veya ortadan kaldırmak için sporun önemli araç olduğu gösterilmek istenmiştir. Bu kapsamda spor lisesi ve spor bilimleri fakültesi öğrencilerindeki öfke ve saldırganlık düzeylerinin ortaya konması ve karşılaştırılması amaçlanmıştır. 


\section{Metod}

Araştırmada spor lisesinden 113 ve Yaşar Doğu spor bilimleri fakültesinden 146 toplam 259 öğrencinin doldurduğu ölçek değerlendirilmiştir. Eksik doldurulan anketler değerlendirme dışı bırakılmıştır. Gönüllülük esasina göre anketler doldurulmuştur.

\section{Veri toplama}

Veri toplama aracı olarak "Sürekli Öfke-Öfke ifade Tarz Ölçeği” ile Buss ve Perry Saldırganlık ölçeği kullanılmıştır.

Sürekli Öfke-Öfke ifade Tarz Ölçeği: Bu ölçek Spielberger (1988) tarafından geliştirilmiş ve Özer (1994) tarafından Türkçe 'ye uyarlaması yapılmiştır. Sürekli öfke ölçek maddeleri 10 adet, öfke tarz ölçeği maddeleri 24 adettir. Öfke tarz ölçeği üç alt boyuttan oluşur. Bunlar öfke içte (veya Bastırılmış Öfke = 8 madde), öfke dışta (veya Dışa Vurulmuş Öfke= 8 madde) ve Öfke kontroldür (veya Kontrol Altına Alınmış Öfke= 8 madde). Ölçek 4'lü Likert tipi bir ölçektir. Soruların hepsi olumludur (düzdür).Hemen hiçbir zaman (1), bazen (2), çoğu zaman (3) ve Hemen her zaman (4) olarak puanlanır. Sürekli Öfke 'den alınan yüksek puanlar, öfke düzeyinin yüksek olduğunu; Kontrol Öfke ölçeğindeki yüksek puanlar öfkenin kontrol edilebildiğini; Öfke Dışta ölçeğindeki yüksek puanlar, öfkenin kolayca ifade edilebildiğini ve Öfke içte ölçeğindeki yüksek puanlar ise öfkenin bastırılmış olduğunu göstermektedir (Esen ve Çelikkaleli, 2002).

Saldırganlık ölçeği: Buss ve Perry tarafından geliştirilen, Andaç Demirtaş tarafından (2012) güvenirlik çalışması yapılarak Türkçeye çevrilen "saldırganlık ölçeği" kullanılmıştır. Anket 5'li likert tipi ölçek şeklinde uygulanmıştır. Fiziksel saldırganlık, sözel saldırganlık, düşmanlık ve öfke olmak üzere saldırganlığın dört farklı boyutunu ölçmeyi amaçlamaktadır. Fiziksel saldırganlık alt ölçeği, başkalarına fiziksel olarak zarar verme ile ilişkili 9 soru; sözel saldırganlık alt ölçeği, başkalarını sözel yolla incitmeyi içeren 5 soru; öfke alt ölçeği, saldırganlığın duygusal boyutunu ölçmeyi 
hedefleyen 7 soru; düşmanlık alt ölçeği ise saldırganlığın bilişsel boyutunu ölçmeyi hedefleyen 8 soru içermektedir. Bu çalışmada saldırganlık ölçeğinin iç tutarlığ 0.82 elde edilmiştir.

\section{İstatistiksel işlemler}

Verilerin değerlendirilmesinde SPSS 22 paket programı kullanılmıştır. Verilerin normal dağılıp dağılmadığını test etmek için Kolmogorov-Smirnov testi yapılmış ve verilerin normal dağılım gösterdiği tespit edilmiştir. İstatistiksel farklılıklar için Bağımsız gruplarda t- testi kullanılmıştır.

\section{Bulgular}

Spor lisesi ve spor bilimleri fakültesi öğrencilerinin antropometrik özellikleri tablo 1'de verilmiştir. Tablo 2 ve 3 'de öfke durumları verilmiştir. Tablo 4 ve 5'de saldırganlık durumları verilmiştir. Tablo 6 'da öfke ve saldırganlık durumlarının birbirleri ile ilgili korelasyon değerleri bulunmaktadır.

Tablo 1. Öğrencilerin cinsiyete göre yaş, boy uzunluğu ve vücut ağırlı̆̆ı ortalamaları

\begin{tabular}{llllll}
\hline Alt boyutlar & Cinsiyet & N & Ortalama & SS & t- testi \\
\hline \multirow{2}{*}{ Yaş (yıl) } & Kadın & 136 & 17,02 & 2,66 & \multirow{2}{*}{$-6,44^{* *}$} \\
& Erkek & 123 & 20,71 & 6,06 & \\
\multirow{2}{*}{ Boy uzunluğu $(\mathrm{cm})$} & Kadın & 136 & 160,48 & 10,42 & $-13,18^{* *}$ \\
& Erkek & 123 & 175,28 & 7,16 & \\
\multirow{2}{*}{ Vücut ağırlı̆̆ı $(\mathrm{kg})$} & Kadın & 136 & 50,84 & 11,51 & $-13,39^{* *}$ \\
& Erkek & 123 & 70,04 & 11,53 & \\
\hline
\end{tabular}

${ }^{* *} p<0,001$

Tablo 2. Öğrencilerin cinsiyete göre öfke puanlarının karşılaştırılması

\begin{tabular}{llllll}
\hline Alt boyutlar & Cinsiyet & N & Ortalama & SS & t-testi \\
\hline \multirow{2}{*}{ Sürekli öfke } & Kadın & 136 & 19,35 & 5,51 & \multirow{2}{*}{$-4,03^{* *}$} \\
& Erkek & 123 & 22,01 & 5,05 & \\
Öfke içte & Kadın & 136 & 16,24 & 4,44 & $-1,22$ \\
\multirow{2}{*}{ Öfke dişta } & Erkek & 123 & 16,88 & 3,82 & \\
& Kadın & 136 & 15,72 & 5,13 & \multirow{2}{*}{$-3,38^{* *}$} \\
Öfke kontrol & Erkek & 123 & 17,67 & 4,05 & \\
& Kadın & 136 & 21,91 & 4,55 & \multirow{2}{*}{1,15} \\
\hline
\end{tabular}

** $p<0,001$ 
Öğrencilerin cinsiyete göre yaş, boy uzunluğu, vücut ağırlığı ortalamalarına bakıldığında tüm parametrelerde kadınların erkeklere göre daha düşük ortalamaya sahip olduğu görülmüştür

Cinsiyete göre öğrencilerinin öfke kontrol puanları erkelerde 21,28 ve kadınlarda 21,91 puan olarak bulunmuştur. Sürekli öfke, öfke içte ve öfke dışta puanları kadınlarda erkelerden daha düşüktür.

Tablo 3. Spor lisesi ve spor bilimleri fakültesi öğrencilerinin öfke puanlarının dă̆ılımı

\begin{tabular}{llllll}
\hline Alt boyutlar & Öğrenci & N & Ortalama & SS & t-testi \\
\hline \multirow{2}{*}{ Sürekli öfke } & Spor Lisesi & 113 & 19,28 & 5,07 & \multirow{2}{*}{$-3,84^{* *}$} \\
& Spor bilimleri & 146 & 21,82 & 5,52 & \\
Öfke içte & Spor Lisesi & 113 & 16,20 & 4,46 & $-1,25$ \\
& Spor bilimleri & 146 & 16,85 & 3,86 & \\
Öfke dişta & Spor Lisesi & 113 & 15,20 & 4,96 & \multirow{2}{*}{$-4,90^{* *}$} \\
& Spor bilimleri & 146 & 17,96 & 4,13 & \\
Öfke kontrol & Spor Lisesi & 113 & 22,00 & 4,52 & \multirow{2}{*}{$-1,97^{*}$} \\
& Spor bilimleri & 146 & 21,27 & 4,32 & \\
\hline
\end{tabular}

${ }^{*} p<0,05 \quad{ }^{* *} p<0,001$

Spor lisesi ve spor bilimleri fakültesi öğrencilerinin öfke kontrol puanlarına bakıldığında spor lisesi öğrencilerinin 22,00 puan ve spor bilimleri fakültesi öğrencilerinin ise 21,27 puan olarak bulunmuştur. Sürekli öfke, öfke içte ve öfke dışta puanları spor lisesi öğrencilerinin spor bilimleri fakültesi öğrencilerinden daha düşüktür.

Tablo 4. Öğrencilerin cinsiyete göre saldırganlık puanları karşılaştırılması

\begin{tabular}{lllllc}
\hline Alt boyutlar & Cinsiyet & $\mathbf{N}$ & Ortalama & SS & t- testi \\
\hline \multirow{2}{*}{ Fiziksel saldırganlık } & Kadın & 136 & 20,05 & 7,59 & \multirow{2}{*}{$-5,39^{* *}$} \\
& Erkek & 123 & 24,39 & 4,92 & \\
Düşmanlık & Kadın & 136 & 24,07 & 6,66 & $4,04^{* *}$ \\
\multirow{2}{*}{ Öfke } & Erkek & 123 & 21,17 & 4,59 & \\
\multirow{2}{*}{ Sözel saldırganlık } & Kadın & 136 & 18,51 & 5,64 & 1,18 \\
& Erkek & 123 & 19,26 & 4,31 & \\
\multirow{2}{*}{ Toplam saldırganlık } & Kadın & 136 & 13,88 & 4,14 & $-1,37$ \\
& Erkek & 123 & 14,53 & 3,43 & \\
& Kadın & 136 & 76,51 & 20,01 & $-1,32$ \\
\hline
\end{tabular}

${ }^{* *} p<0,001$

Öğrencilerin cinsiyete göre saldırganlık puanlarına bakıldığında toplam saldırganlıkta erkekler 79,35 puan ve kadınlar 76,51 puan almıştır. 
Her ne kadar istatistiksel olarak anlamlı farklılık bulunmazsa da erkelerin toplam saldırganlık puanları kadınlardan daha yüksektir.

Tablo 5. Spor lisesi ve spor bilimleri fakültesi öğrencilerinin saldırganlık puanlarının dă̆ılımı

\begin{tabular}{llllll}
\hline Alt boyutlar & Öğrenci & N & Ortalama & SS & t-testi \\
\hline \multirow{2}{*}{ Fiziksel saldırganlık } & Spor Lisesi & 113 & 19,63 & 6,82 & \multirow{2}{*}{$5,93^{* *}$} \\
& Spor bilimleri & 146 & 24,35 & 5,98 & \\
Düşmanlık & Spor Lisesi & 113 & 23,07 & 6,65 & \multirow{2}{*}{0,97} \\
\multirow{2}{*}{ Öfke } & Spor bilimleri & 146 & 22,35 & 5,22 & \multirow{2}{*}{ Sözel saldırganlık } \\
& Spor Lisesi & 113 & 18,14 & 4,79 & \multirow{2}{*}{$-2,23^{*}$} \\
& Spor bilimleri & 146 & 19,53 & 5,21 & \multirow{2}{*}{ Saldırganlık toplam } \\
& Spor Lisesi & 113 & 13,99 & 3,95 & \multirow{2}{*}{$-0,77$} \\
& Spor bilimleri & 146 & 14,36 & 3,72 & \multirow{2}{*}{ ( } \\
& Spor Lisesi & 113 & 74,84 & 17,28 & \multirow{2}{*}{$-2,72^{*}$} \\
\hline
\end{tabular}

${ }^{*} p<0,05 \quad{ }^{* *} p<0,001$

Spor lisesi ve spor bilimleri fakültesi öğrencilerinin saldırganlık puanlarına göre toplam saldırganlıkta liseli öğrenciler 74,80 puan ve spor bilimleri fakültesi öğrencileri 80,60 puan almıştır. Spor lisesi öğrencilerinin spor bilimleri fakültesi öğrencilerine göre saldırganlık puanları daha düşüktür.

Tablo 6. Öğrencilerin öfke ve saldırganlık ölçek puanları arasındaki ilişkiler

\begin{tabular}{|c|c|c|c|c|c|c|c|c|}
\hline & Öİ & ÖD & ÖK & FS & D & Ö & SS & TS \\
\hline sÖ &, $54^{* *}$ &, $75^{* *}$ &,$- 30^{* * *}$ & ,61* & , $42^{* *}$ & ,67*t & ,51* & , $70^{* *}$ \\
\hline Öİ & &, $62^{* *}$ &,$- 15^{*}$ &, $32^{* *}$ &, $53^{* *}$ &, $48^{* *}$ &, $34^{* *}$ &, $53^{* *}$ \\
\hline ÖD & & &,$- 33^{* *}$ & ,62* & , $39^{* *}$ & , $70^{* *}$ &, $46^{* *}$ & ,69* \\
\hline ÖK & & & &,$- 51^{* *}$ &,$- 16^{* *}$ &,$- 43^{* *}$ &,$- 23^{* *}$ &,$- 44^{* * *}$ \\
\hline FS & & & & &, $32^{* *}$ & $68^{* *}$ &, $52^{* *}$ & , $82^{* *}$ \\
\hline D & & & & & & ,51** &, $43^{* *}$ & ,72** \\
\hline Ö & & & & & & &, $56^{* *}$ &, $86^{* *}$ \\
\hline SS & & & & & & & &, $75^{* *}$ \\
\hline
\end{tabular}

${ }^{*} p<0,05 v e^{* *} p<0,001$

Sürekli Öfke (SÖ), Öfke içte (ÖI), Öfke Dışta (ÖD), Öfke kontrol (ÖK), Fiziksel Saldırganlık (FS), Düşmanlık (D), Öfke (Ö), Sözel saldrrganlık (SS) ve Toplam saldrrganlık (TS).

Öfke ve saldırganlık puanları korelasyonlarına bakıldığında Öfke kontrolünün diğer öfke alt ölçekleri ve saldırganlık alt ölçek ve toplam ölçek puanları ile negatif ilişkisi vardır. Diğer parametreler birbiri ile pozitif ilişki içerisindedir. 


\section{Tartışma}

Çalışmaya katılan öğrencilerin yaş ortalamaları erkeklerde 20,71 yıl ve kadınlarda 17,02 yıl şeklindedir. Boy uzunlukları kadınlarda 160,48 cm ve erkelerde 175,28 cm iken vücut ağırlıkları kadınlarda 50,88 kg ve erkeklerde 70,04 kg bulunmuştur. Cinsiyete göre yaş, boy uzunluğu ve vücut ağırlıkları arasındaki farklılıklar anlamlıdır $(\mathrm{p}<0,001)$.

Cengiz ve ark. (2018) üniversite öğrencilerinde Sürekli Öfke-Öfke İfade Tarzı Ölçeği puanları ile cinsiyetleri arasında anlamlı farklılık bulmamıştır. Atay ve ark. (2017) çalışmalarında sürekli öfke alt ölçeği puanlarını sedanterlerde 21,73 puan ve güreşçilerde 22,51 puan olarak bulmuşlardır. Diğer boyutlarda da benzer puan durumu vardır. Bu çalışmada sürekli öfke puanı kadınlarda 19,35 puan ve erkeklerde 22,01 puan, Öfke içte erkeklerde 16,88 puan ve kadınlarda 16,24 puan olarak bulunmuştur. Öfke dışta ise kadınlarda 15,72 puan ve erkeklerde 17,67 puan iken öfke kontrol kadınlarda 21,29 puan ve erkeklerde 21,28 puan alınmıştır. Cinsiyete göre sürekli öfke durumunda ve öfke dışta anlamlı farklılık varken $(\mathrm{p}<0,05)$ ve öfke içte ve öfke kontrol şekilleri arasında anlamlı bir farklılık bulunmamıştır (p>0,05). Yöndem ve Bıçak'ın (2008) Eğitim Fakültesi'nde okuyan üniversite öğrencileri üzerinde yaptıkları çalışmalarında; cinsiyete göre öfke kontrolü yönünden her iki cinsiyette benzerlikler gözlenirken, erkeklerin kızlara kıyasla öfke düzeyinin, içe yönelik ve dışa yönelik öfkelerinin anlamlı düzeyde yüksek olduğu bulunmuştur. Bostancı ve ark. (2006 ) üniversite öğrencileri ile yaptıkları bir diğer çalışmada ise öfke belirtileri yönünden kızlar ve erkekler arasında fark bulunmamıştır. Öfkenin ifade tarzının cinsiyete göre değişiklik gösterdiği çalışmalar da bulunmaktadır (Balkaya ve Şahin, 2003; Tambağ ve Öz, 2005). Batıgün ve Utku (2006) ve Tambağ ve Öz (2005) çalışmalarında kadınların öfkelerini daha fazla içe atma eğiliminde olduğunu, çünkü toplumsal kurallar gereği kadınların öfkelerini dışa vurduklarında kontrolsüz ve zayıf, erkeklerin ise öfkelerini dışa vurduklarında güçlü ve erkeksi algılandığını göstermektedir. Bayanlar öfkelerini erkeklerden daha az dışa vurdukları için öfke birikmekte ve sürekli öfkenin erkeklerden yüksek çıkmasına neden olmaktadır. Karadağ (2018) çalışmasında Kick boks sporcularında bayanların erkeklere göre biraz daha fazla öfkelerini dışa vurdukları yani öfkenin kolayca ifade ettik- 
leri belirtilmiştir. Bu çalışmada ise erkeklerin sürekli öfke düzeyi kadınlardan daha yüksek olduğu söylenebilir. Öfke dışta erkeklerin kadınlardan aldığı puanın daha yüksek olması onların kadınlara göre öfkelerini daha kolayca ifade edebildikleri şeklinde yorumlanabilir. Bu çalışma Kick boks sporcuları dışında burada bahsedilen çalışmaları desteklemektedir.

Öfke dışta ölçeğindeki yüksek puanlar, öfkenin kolayca ifade edilebildiğini ve Öfke içte ölçeğindeki yüksek puanlar ise öfkenin bastırılmış olduğunu göstermektedir (Esen ve Çelikkaleli, 2002). Elkin ve Karadağlı (2016) çalışmalarında öğrencilerin yaşı ile sürekli öfke ve öfke ifade tarzları arasında istatistiksel olarak anlamlı bir ilişki bulunmamıştır. Kaya ve ark. (2012) çalışmasında ise öğrencinin yaşı arttıkça kontrol altına alınmış öfke puanlarının düştüğü görülmüştür. Akpınar ve ark. (2012) çalışmasinda dışa vurulan öfkede yaş değişkenine göre anlamlı bir fark bulmuştur. Nas ve ark (2018) çalışmalarında ise dışa vurulan öfkede yaş değişkenine farklı iken içe vurulan öfkeyle ilgili her hangi bir fark bulunmamıştır. $\mathrm{Bu}$ çalışmada lise öğrencileri doğal olarak üniversite öğrencilerine göre daha küçük yaştadır. Bu çalışmada spor bilimleri fakültesi öğrencilerinin sürekli öfke puanı 21,82 iken lise öğrencilerinde 19,28 puandır. Öfke içte puanı spor lisesi öğrencilerinde 16,20 puan ve spor bilimleri fakültesi öğrencilerinde 16,85 puandır. Yine öfke dişta puanı spor bilimleri fakültesi öğrencilerinde 17,96 puan ve spor lisesi öğrencilerinde 15,20 puandır. Öfke kontrol boyutunda ise spor bilimleri fakültesi öğrencilerinde 21,27 ve spor lisesi öğrencilerinde 22,00 puandır. Lise ve spor bilimleri fakültesi öğrencilerinin sürekli öfke ve öfke ifade şekilleri arasında (öfke içte hariç) anlamlı bir farklılık bulunmuştur $(p<0,05, p<0,001)$. Üniversite öğrencilerinde sağlık durumunun iyi olması ile insanların kendini güçlü hissetme veya olumlu kişilik özellikleri artırabilir (İmamoğlu, 2017). Hatta kişilik özellikleri eğitimle olumlu yönde değişir (İmamoğlu ve Demirtaş, 2017; Koca ve ark., 2018). Düzenli olarak fiziksel aktivite ya da spor yapan genç birey ve gruplar yapmayanlara oranla psikolojik, sosyolojik ve fiziksel olarak daha üstün durumdadırlar (İmamoğlu ve ark.,2018). Bu çalışmada sürekli öfke ve öfke dışta boyutlarında üniversite öğrencilerinin daha yüksek puan almaları üniversite öğrencilerinin öfke düzeyinin daha yüksek oluşu ve öfkelerini daha kolay dışa yansıtabildikleri şeklinde yorumlana- 
bilir. Öfke kontrol boyutunda ise lise öğrencilerinin üniversite öğrencilerine göre daha yüksek puan almaları öfkelerini daha iyi kontrol edebildiklerini düşündürmektedir. Bu durum beklenmeyen bir sonuçtur.

Cinsiyet değişkeni açısından yapılan karşılaştırmalarda, erkek öğrencilerin saldırganlıklarının kızlardan daha yüksek olduğu sonucuna ulaşılmıştır (Camadan ve Yılmaz, 2017). Ölçeğin geliştiricisi Buss ve Perry (1992), erkeklerin fiziksel saldırganlık ve sözel saldırganlık puanlarının kadınlarınkinden anlamlı düzeyde yüksek olduğunu belirtmişlerdir. Ceylan (2012) çalışmasında cinsiyetler açısından erkekleri daha saldırgan bulmuştur. Duygu (2012) spor eğitimi alan öğrencilerde saldırganlık düzeylerinin cinsiyetlere göre değiştiğini bulmuştur. Erşan ve ark. (2009) çalışmalarında saldırganlık ölçeği puan ortalamalarını arasındaki yaşa, cinsiyete, bölüm ve branşa göre farklar istatistiksel yönden anlamlı bulmamıştır. Demirtaş ve ark. (2018) bir çalışmada Üniversite de spor ve güzel sanatlar eğitimi alan öğrencilerde atılganlık dışında benzer saldırganlık eğilimi bulmuştur. Bu benzerlik nedenleri olarak aldıkları spor ve sanat eğitiminin etkili olduğu gösterilmiştir. Andaç saldırganlık geçerlilik çalışmasinda (2012) toplam saldırganlık puanını erkelerde 82,00 ve kadınlarda 80,78 olarak bulmuştur. Andaç (2012) çalışmasında sadece fiziksel saldırganlık puanları açısından bir cinsiyet farklılığı olduğunu belirtmiştir. Erkeklerin bu alt ölçekten aldıkları puanlar kadınların puanlarından anlamlı ölçüde yüksektir. Bu çalışmada fiziksel saldırganlık puanını erkeklerde 24,39 ve kadınlarda 20,05 bulunurken, düşmanlık erkeklerde 21,17 ve kadınlarda 24,07 puan, öfke erkeklerde 19,26 ve kadınlarda 18,51 puan, sözel saldırganlık erkeklerde 14,53 ve kadınlarda13,88 puan bulunmuştur. Ölçek toplam saldırganlık puanını ise erkelerde 79,35 puan ve kadınlarda 76,51 puan olarak bulmuştur. Bu çalışmada cinsiyete göre fiziksel saldırganlık ve düşmanlık alt boyutunda anlamlı bir farklılık bulunmuştur $(p<0,05)$. Öfke ve sözel saldırganlık alt boyutunda ve toplam saldırganlıkta cinsiyete göre anlamlı bir farklılık bulunmamıştır ( $>>0,05)$.

Bu çalışmada spor lisesi ve spor bilimleri fakültesi öğrencilerinde fiziksel saldırganlık ve öfke alt boyutu ile toplam saldırganlıkta anlamlı bir farklılık bulunmuştur ( $p<0,05$ ve $p<0,001$ ). Üniversite öğrencilerinin fiziksel saldırganlık, öfke ve toplam saldırganlık puanları lise öğrencilerinden yüksektir. Öğrencilerin umutsuzluk düzeyi stres düzeyini artırabilir (İma- 
moğlu ve Demirtaş, 2017). Bir çalışmada Üniversite spor eğitimli öğrencilerin liderlik yönelimlerinin iyi olduğu belirlenmiştir (Çetinkaya ve İmamoğlu,2018). Sporun üniversite öğrencilerinde anksiyeteyi düşürdüğü bulunmuştur (Ermiş ve İmamoğlu, 2019). Camadan ve Yazıcı (2017) çalışmalarında üniversite öğrencilerinin saldırganlıklarının sınıf düzeyinden etkilendiği belirtilmiştir. Medyada yer alan saldırganlığın model alma yoluyla takip edilmesinin, sergilenen saldırgan davranışlara duyarsızlaşarak veya dünyanın ve yaşamın güvensiz bir ortam olduğu algısına sahip olunarak bireylerin saldırganlığa eğilim göstermelerine yol açtığı ifade edilmiştir. Yukarıda yapılan değerlendirmeler çerçevesinde lise öğrencilerine göre üniversite öğrencilerinin daha saldırgan olmaları normal bir durumdur. İnsanların gündelik hayatlarında veya eğitim ortamlarındaki ihtiyaçlarını gidermede zorlanmaları saldırganlığa neden olabilir. Bu nedenle de üniversite öğrencilerinin bir kısmının ailelerinden uzakta olmaları ve ekonomik sıkıntıyı daha fazla hissetmeleri de etkili olabilir.

$\mathrm{Bu}$ çalışmada öfke ve saldırganlık ölçekleri alt ölçekler ve toplam puanlar arasında öfke kontrolü hariç pozitif korelayonlar bulunmuştur. Öfke kontrolü ile ise negatif korelayonlar bulunmuştur ( $p<0,05$ ve $p<0,001)$. Sürekli öfke, öfke içte ve öfke dışta puanı arttıkça öfke kontrolü d puanı düşmektedir. Yine öfke kontrolü puanı arttıkça saldırganlık ölçek puanları düşmektedir. Spor lisesi ve Spor bilimleri fakültesi öğrencilerinin öfke kontrol düzeylerinin düşürülmesi öfkelerini kontrol altına alma ve saldırganlıklarını azaltmak için önemli görülmüştür.

\section{Sonuç ve Öneriler}

Erkeklerin sürekli öfke düzeyi kadınlardan daha yüksek olduğu söylenebilir. Erkekler kadınlara göre öfkelerini daha kolayca ifade edebilmişlerdir. Spor bilimleri fakültesi öğrencileri spor lisesi öğrencilerine göre öfkelerini daha kolay dışa yansıtabilmektedirler. Spor lisesi öğrencileri Spor bilimleri fakültesi öğrencilerine göre öfkelerini daha iyi kontrol edebilmişlerdir. Yine cinsiyete göre fiziksel saldırganlık ve düşmanlık boyutlarında farklılık bulunmuştur. Spor bilimleri fakültesi öğrencilerinin spor lisesi öğrencilerine göre saldırganlık düzeyleri daha yüksektir. Öfkeyi kontrol etme ve Saldırganlık düzeylerini düşürücü eğitim ve seminerlere yer verilmelidir. 


\section{EXTENDED ABSTRACT}

\section{Investigation of Anger and Aggression Levels of Sports High School and Sports Science Faculty Students}

Bade Yamak - Osman İmamoğlu - Murat Eliöz - Mehmet Çebi -İzzet İslamoğlu Samsun On Dokuz Mayıs University

In this study, it was aimed to investigate the anger-anger expression patterns and aggression levels of sports high school and sports science faculty students. In the study, a questionnaire consisting of 113 students from sports high school and 146 students from Yaşar Doğu sports sciences faculty was evaluated. "Trait Anger-Anger Expression Style Scale" and Buss and Perry Aggression Scale were used as data collection tools. Kolmogorov-Smirnov test was used to test the normal distribution of the data and it was determined that the data showed normal distribution. Independent $\mathrm{t}$-test was used for statistical differences. The mean age of the students was 20.71 years for males and 17.02 years for females. Length length was 160,48 $\mathrm{cm}$ in females and $175,28 \mathrm{~cm}$ in males whereas body weight was $50,88 \mathrm{~kg}$ in females and 70,04 kg in males. The differences between age, height and body weights were significant $(\mathrm{p}<0.001)$. Anger control scores of the students by gender were 21.28 for males and 21.91 for females. The scores of trait anger, anger inside and outside anger were lower in women than men. There was a significant difference $(\mathrm{p}<0.05)$ between the anger status and the anger control styles ( $>>0.05)$. Anger control scores of sports high school and sports faculty students were 22.00 points for sports high school students and 21.27 points for sports faculty students. The scores of trait anger, anger inside and anger outside were lower in sports high school students than in sports faculty students. There was a significant difference between high anger and anger expressions (except anger inside) $(\mathrm{p}<0.05$, $\mathrm{p}<0.001$ ). In the comparison of the students' Aggression Points by Gender, the total aggression score was 79.35 points for males and 76.51 points for females. Although no statistically significant difference was found, total 
aggression scores of males were higher than females. There was a significant difference in physical aggression and hostility sub-dimension according to gender $(p<0.05)$. There was no significant difference in anger and verbal aggression sub-dimension and total aggression by gender $(p>0.05)$. Distribution of Aggression Levels Scores According to the Status of Being a Student of Sports High School and Sports Faculties In total aggression, high school students received 74.80 points and university students scored 80.60 points. Distribution of Aggression Levels Scores According to the Status of Being a Student of Sports High School and Sports Faculties In total aggression, high school students received 74,80 points and university students scored 80,60. Aggression scores of sports high school students are lower than sports school students. There was a significant difference between physical aggression and anger subscale and total aggression among sports high school and sports faculty students ( $p<0.05$ and $\mathrm{p}$ $<0.001$ ). There were positive correlations between anger and aggression scales and total scores except anger control. There were negative correlations with anger control ( $p<0.05$ and $p<0.001)$. As the scores of continuous anger, anger inside and outside anger increased, anger control d score decreased. Again, as anger control score increases, aggression scale scores decrease. Reducing anger control levels of sports high school and sports faculty students has been seen as important for controlling their anger and reducing their aggression.

It can be said that men's anger level is higher than women. Men were able to express their anger more easily than women. Sports faculty students can express their anger more easily than sports high school students. Sports high school students were better able to control their anger than university students. Also, there was a difference in physical aggression and hostility according to gender. Aggression levels of university students are higher than sports high school students. Training and seminars to control anger and reduce aggression should be included

\section{Kaynakça / References}

Akpınar, S., Temel, V. ve Nas, K. (2012). Determination of students' trait anger and anger expression styles who are studying at physical education and sports high school. Prime journal of social science (PJSS), 1(3), 46-50. 
Alden, L. E. ve Wallace, S. T. (1995). Social phobia and social appraisal in successful and unsuccessful social interactions. Behavior Research and Therapy, 33, 497-505.

Andaç, D. M. (2012). Buss peri saldırganlık ölçeğinin Türkçe formunun geçerlik ve güvenirlik çalışması. Türk Psikiyatri Dergisi,23, 1-6.

Atay, E., Tanır, H., Çetinkaya, E. ve Kaya E. (2017). Sedanter kadınlar ile ve güreşçi kadınların öfke düzeylerinin karşılaştırılması, The Journal of Academic Social Science Studies, 64, 507-511.

Balkaya F., ve Şahin N. H. (2003). Çok boyutlu öfke ölçeği. Türk Psikiyatri Dergisi, 14(3), 192-202.

Bandura, A. (1986). Social foundation of thought and action: A social theory. Englewood Cliffs, Nj: Prentice Hall.

Bandura, A. (1989). Regulation of cognitive process through perceived selfefficacy. Developmental Psychology, 25(5), 729-735.

Bandura, A., Barbaranelli, C., Caprara, G., V., ve Pastorelli, C. (1999). Self-efficacy pathways to childhood depression. Journal of Personality end Social Psychology, 35, 1110-1119.

Batıgün, A. ve Şahin, N. (2003). Öfke, dürtüsellik ve problem çözme becerilerindeki yetersizlik gençlik intiharlarının habercisi olabilir mi? Türk Psikoloji Dergisi, 18(51), 37-52.

Bilgin, N. (1988). Sosyal psikolojize giriş. İzmir: Ege Üniversitesi Edebiyat Fakültesi Yayınları.

Bostancı, N., Çoban, Ş., Tekin Z. ve Özen A. (2006). Üniversite öğrencilerinin cinsiyete göre öfke ifade etme biçimleri, Kriz Dergisi. 14(3), 9-18.

Boxer, P. ve Tisak, M. S. (2005). Children's beliefs about the continuity of aggression. Aggressive Behavior, 31(2), 172-188.

Buss, A.H. ve Perry M. (1992). The aggression questionnaire. J Pers Soc Psych, 63, 452-9.

Camadan, F. ve Yazıc1, H. (2017). Investigation of the aggression tendency observed in university students in terms of different variables. Journal of Higher Education and Science, 7(2), 225-234.

Canbuldu, S. (2006). Çok boyutlu öfke envanteri'nin uyarlama çalı̧̧ması. Doktora Tezi, Mersin Üniversitesi, Sosyal Bilimler Enstitüsü, Psikolojik Danışma ve Rehberlik Anabilim Dalı.

Ceylan, D. (2012). BESYO öğrencilerinin saldırganlık düzeylerinin incelenmesi. Mezuniyet Tezi, Çanakkale Onsekiz Mart Üniversitesi Beden Eğitimi Ve Spor Yüksek Okulu Spor Yöneticiliği Bölümü. 
Çengiz, R., Koçak, F. ve Sunay, H.(2018). Investigation of the level of anger and impulsive behavior of the high school of physical education and sports students. Spormetre, 16(1), 29-38.

Çetinkaya, G. ve İmamoğlu, G. (2018). Research on leadership tendency of students taking sports education according difference variations. The Journal of International Social Research, 11(59), 719-725.

Demirtaş, A.M. (2012). Saldırganlık ölçeğinin Türkçe formunun geçerlilik ve güvenirlik çalışması, Türk Psikiyatri Dergisi, 23, 1-5.

Dervent, F., Arslanoğlu E. ve Şenel Ö. (2010). Lise öğrencilerinin saldırganlık düzeyleri ve sportif aktivitelere katılımla ilişkisi:İstanbul İli Örneği. Uluslararası İnsan Bilimleri Dergisi, 7(1), 523-525.

Demirtaş, Ö., İmamoğlu, G. ve Yamaner, F. (2018). Üniversitede spor ve güzel sanat eğitimi alan bireylerin saldırganlık düzeylerinin incelenmesi. 6. Uluslararası Bilim Kültür ve Spor Kongresi Bildiri Kitabı içinde (s.696-706.) Tarih, Ankara. ISBN 978-605-83344-6-5.

Elkin, N. ve Kardağll, F. (2016). Anger expression and related factors in university students, Anatol Clin, 21(1), 64-71.

Ermiş, E. ve İmamoğlu, G. (2019). The effects of sport education and fine arts education on social appearance anxiety. Journal of Education and Training Studies, 7(6), 1-6.

Esen, B.K. ve Çelikkaleli, Ö. (2002). Üniversite öğrencilerinin sosyal yetkinlik düzeyleri ile sürekli öfke ve öfke ifade biçimlerinin incelenmesi, Türk Psikolojik Danısma ve Rehberlik Dergisi, 3(29), 37-49.

Erdoğdu, M., Koçyiğit, M., Kayışoğlu, N.B. ve Yılmaz, B. (2018). futbol ve futsal branşlarında spor yapan genç kadınların saldırganlık yaklaşımları. Uluslararası Kültürel ve Sosyal Araştırmalar Dergisi (UKSAD), 4(SI), $1-14$.

Erşan, E.E., Doğan O. ve Doğan S. (2009). Beden eğitimi ve spor yüksekokulu öğrencilerinin saldırganlık düzeylerinin sosyodemografik açıdan değerlendirilmesi, Cumhuriyet Tip Dergisi, 31, 231-238.

Genç, H. (2007). Grupla öfke denetimi eğitiminin lise 9. sını öğrencilerinin sürekli öfke düzeylerine etkisi. Yüksek Lisans Tezi, Dokuz Eylül Üniversitesi Eğitim Bilimleri Enstitüsü Eğitim Bilimleri Anabilim dalı Rehberlik ve Psikolojik Danışmanlık Programı.

İmamoğlu, G. (2017). The investigation of the beck hopelessness scale and characteristics in fine art and basic education students. İdil, 6(37), 1-20. 
İmamoğlu, G. (2017). The comparison of the self-perceptions of individuals with and without art education. Journal of Current Researches on Social Sciences, 7 (2), 375-384.

İmamoğlu, G. ve Demirtaş, Ö. (2017). Investigation of students' views who receive art and religious training about body image, International Journal of Cultural and Social Studies (IntJCSS), 3(SI), 476-483.

İmamoğlu, G., Koca F. ve Gönülateş, S. (2018). Research on the attitudes of the students towards visual arts studying in sports and music education departments. The Journal of Academic Social Science, 6(81), 1-13.

Karadağ, M. (2018). Examination the anger management levels of the athletes in kickbox teams. Journal of History School (JOHS), 11(33), 1157-1175.

Kaya, N., Kaya, H., Atar, N., Turan, N., Eskimez, Z., Palloş, A. ve Aktaş A. (2012). Hemşirelik ve ebelik öğrencilerinin öfke ve yalnızlık özellikleri, Hemşirelikte Ĕ̆itim ve araştırma Dergisi, 9(2), 18-26.

Koca, F., İmamoğlu, G. ve İmamoğlu O. (2018). Sports status of high school students and investigation of personality characteristics by gender. The Journal of Academic Social Science, 6(80), 31-42.

Kökdemir, H. (2004). Öfke ve öfke konrolü. Pivolka, 3(12), 7-10.

Kesen, N.F., Deniz, M.E ve Durmuşoğlu, N. (2007). Ergenlerde saldırganlık ve öfke düzeyleri arasındaki ilişki: Yetiştirme yurtları üzerinde bir araştırma. SÜ. Sosyal Bilimler Enstitüsü Dergisi, 17,353-64.

Nas, K., Birol, S.Ş. ve Temel, V. (2016). Futsalcıların öfke tarzlarının bazı değişkenler açısından belirlenmesi. Inonu University, Journal of Physical Education and Sport Sciences, 3(1), 10-22.

Özer, A. K. (1994). Sürekli öfke (SL-ÖFKE) ve öfke ifade tazı (ÖFKE-TARZ) ölçekleri ön çalışması. Türk Psikoloji Dergisi, 31, 26-35.

Ramirez, J. M., ve Andreu, J. M. (2006). Aggression and some related psychological constructs (anger, hostility, and impulsivity): Comments from a research project. Neuroscience \& Biobehavioral Reviews, 30(3), 276-291.

Roberto, A. J., Meyer, G., Boster, F. J., ve Roberto. H. L. (2003). Adolescents' decisions about verbal and physical aggression: An application of the the theory of reasoned action. Human Communication Research, 29(1), 135-147.

Soykan, Ç. (2003). Öfke ve öfke yönetimi. Kriz Dergisi, 11(2), 19-27.

Soysal, A.Ş., Can, H., ve Kılıç, K. M. (2009). Üniversite öğrencilerinde A tipi davranış örüntüsü ile öfke ifadesi arasındaki ilişkinin analizi ve cinsiyetler açısından karşılaştırılması. Klinik Psikiyatri, 12, 61-67. 
Tafrate, R. C., Kassinove, H., ve Dundin, L. (2002). Anger episodes in high and low trait anger community adults. Journal of Clinical Psychology, 58(12), 1573-1590.

Tambağ H., Öz, F. (2005). Aileleriyle birlikte ve yetiştirme yurtlarında yasayan ergenlerin öfke ifade etme biçimleri. Kriz Dergisi, 13(1), 11-21.

Weber, H., ve Wiedig-Allison, M. (2007). Sex differences in anger-related behaviour: Comparing expectancies to actual behaviour. Cognition and Emotion, 21(8), 1669-1698.

Yöndem, Z. D. Ve Bıçak B. (2008). Öğretmen adaylarının öfke düzeyi ve öfke tarzları. Uluslararası insan Bilimleri Dergisi, 5(2), 1-15.

\section{Kaynakça Bilgisi / Citation Information}

Yamak, B., İmamoğlu, O., Eliöz M., Çebi, M. ve İslamoğlu, İ. (2018) Spor Lisesi ve Spor Bilimleri Fakültesi Öğrencilerinin Öfke ve Saldırganlık Düzeylerinin Araştırılması. OPUS-Uluslararası Toplum Araştırmaları Dergisi , 14(20), 314-332. DOI: 10.26466/opus.592641 